\title{
ANESTHESIOLOGY CLINICS
}

\section{FORTHCOMING ISSUES}

\section{September 2018}

Regional Anesthesia

Nabil Elkassabany and Edward Mariano,

Editors

\section{December 2018}

Preoperative Evaluation

Zdravka Zafirova and Richard D. Urman, Editors

\section{March 2019}

Cutting-Edge Trauma and Emergency Care Maureen McCunn, Mohammed Iqbal

Ahmed, and Catherine M. Kuza, Editors

\section{RECENT ISSUES}

March 2018

Quality Improvement and Implementation

Science

Meghan B. Lane-Fall and Lee A. Fleisher, Editors

December 2017

Anesthesia Outside the Operating Room Mark S. Weiss and Wendy L. Gross, Editors

September 2017

Transplantation

Aman Mahajan and Christopher Wray, Editors 